\title{
Effect of Zinc Sulphate and Zinc oxide Nanoparticles on Economic Returns from Strawberry (Fragaria $\times$ ananassa Duch.) cv. Camarosa Cultivation under Protected Conditions of Mid Hills of Himachal Pradesh
}

\author{
Anjali Thakur, Amit Saurabh* and Lakhwinder Kaur \\ ${ }^{1}$ Department of Horticulture, Dr. Khem Singh Gill Akal College of Agriculture, Eternal \\ University, Baru Sahib, Sirmour (H.P.), India \\ ${ }^{2}$ Department of Horticulture, Dr. Khem Singh Gill Akal College of Agriculture, Eternal \\ University, Baru Sahib, Sirmour (H.P.), India \\ *Corresponding author
}

\section{A B S T R A C T}

Keywords

Cultivation, Benefit, Nanoparticles

Article Info

Accepted:

10 January 2021

Available Online:

10 February 2021
The present experiment was conducted at Experimental farm Chhapang, Department of Horticulture, Dr, Khem Singh Gill Akal College of Agriculture, Eternal university, Baru Sahib during the year 2019-20. The experiment comprised of ten different treatment combinations with three replications. The treatments included $\mathrm{ZnSO}_{4}$ at three levels $(0.1,0.3$ and $0.5 \%)$ and $\mathrm{ZnO}$ nanoparticles at three levels (100, 150 and $300 \mathrm{ppm}$ ) with their combinations as well as one control (water application). The results revealed that sprays of $\mathrm{ZnSO}_{4}$ and $\mathrm{ZnO}$ nanoparticles improved the net economic returns from strawberry cultivation and the treatment $\mathrm{T}_{8}\left(\mathrm{ZnSO}_{4} @ 0.3 \%+\right.$ ZnO NPs@150 ppm) recorded maximum selling price of Rs. 4620, profit of Rs. 2157.65 and Benefit cost ratio $(0.87 \%)$.

\section{Introduction}

Strawberry (Fragaria $\times$ ananassa Duch.) is the most important berry fruit in the world. It is a man made hybrid produced by crossing two American species Fragaria chiloensis and Fragaria virginiana. It belongs to family Rosaceae. It is a shallow rooted crop and is cultivated in plains as well as in hills up to an elevation of $3000 \mathrm{~m}$ above mean sea level in humid or dry regions. This crop is sensitive to water deficiency in soil. Strawberry is a short day plant and is grown all over the world. It is the most delicious berry fruit which is cultivated for its aroma, juicy texture, bright red color and sweetness. It is a complete fruit, which contains 98 per cent edible portion with vitamin C (30-100mg/100g) (Ayub et al., 2010). Characteristic aroma of fruit is due to the presence of volatile esters like ethyl hexanoate, methyl hexanoate and linalool etc. It also contains an anticancerous compound called ellagic acid. Ripe fruit contains more lipids than unripe fruits with more oleic acid and low linoleic acid. Red color of fruits is due to the presence of compounds like anthocyanin, pelarogonodin-3-monoglucoside and traces of cynidin. Essential oil is also 
extracted from leaves which contain linalool and nonanal.

Among different micronutrients, zinc plays an important role in cultivation of horticultural crops. Zinc plays structural and functional role in plants and also helps in hormone production in buds (Pandey, 2010). It helps in formation of structural components of a large number of proteins with catalytic or regulatory functions. Zinc is critical for reproductive development of plants as it helps in floral induction that converts vegetative meristem into reproductive one. Foliar application of zinc increase sugars and decreases acidity. It is required for synthesis of tryptophan which is a precursor of auxin and hence helps in reducing fruit drop (Stiles, 2004).

Nanoparticles are naturally occurring or engineered material with at least one dimension and less than $100 \mathrm{~nm}$ in size. Nanoparticles are used for the growth and disease control in plants. Nanoparticles when applied to plants results into many morphological and physiological changes depending upon their properties (Siddiqui et al., 2015). Efficacy of nanoparticles depends upon the chemical composition, size, surface covering, reactivity and dose at which they are used (Kumar et al., 2017). Nanotechnology in horticulture is used for extension of shelf life of many fruits, increasing strength and quality of the produce as well as helps to control growth and development of various microorganisms (Yadollahi et al., 2014).

Application of micronutrient fertilizers in the form of nanoparticles is proved to be an important source to provide nutrients to plants in a controlled way that is essential to mitigate the pollution problems related to fertilizer application (Naderi and Abedi 2012). Nanoparticles can be beneficial or harmful to plants but, zinc nanoparticles have found to be beneficial to the horticulture crops.

Zinc nanoparticles generally increase plant growth and development in certain ways. They are used in agriculture to enhance seed germination and various other properties, yield and quality of fruits, vegetables and other crops are affected by zinc concentration when applied to some extent.

Zinc oxide is most commonly used metal oxide engineered nanomaterials for effective growth in various plants (Aslani et al., 2014). Zinc also improves the shelf life of the crop, which helps in protecting the strawberry crop from post harvest losses and thus the profit could be increased.

The aim of the study is to know about the treatment combination giving maximum profit along with the Benefit cost ratio so that the technology could reach the farmers and improve their livelihood.

\section{Materials and Methods}

The experiment was laid out under protected conditions at experimental farm Chhapang, Department of Horticulture, Dr. Khem Singh Gill Akal College of Agriculture, Eternal University, Baru Sahib, Sirmour during 201920 in Randomized Block Design. The beds of $2 \times 1 \mathrm{~m}$ were prepared and mixed with $10 \mathrm{~kg}$ farm yard manure. The runners of 35-40 days old of variety Camarosa were transplanted at a distance of $45 \times 30 \mathrm{~cm}$ after dipping into $0.2 \%$ Bavistin solution for 5 minutes. During experimental period, plants were fertilized with half dose of Nitrogen (Urea @ 17.39 g/plot) along with full doze of Phosphorus (SSP @ 50 g/plot) and Potassium (MOP @ $13.33 \mathrm{~g} / \mathrm{plot}$ ) and remaining half dose of Nitrogen (Urea @ 17.39 g/plot) was given after flowering period. Experiment comprises 
of 10 treatments of different concentrations of $\mathrm{ZnSO}_{4} \quad(0.1, \quad 0.3$ and $0.5 \%)$ and $\mathrm{ZnO}$ nanoparticles (100, 150 and $200 \mathrm{ppm})$ individually or in combination along with one control which was replicated thrice. Beds were mulched with wheat straw during experiment to conserve soil moisture and also to protect fruits from any soil borne pathogen. At the end of the experiment the cost price, selling price, profit and benefit cost ratio was calculated.

\section{Results and Discussion}

The expenses incurred and income generated plays an important role in cultivation of any crop and is considered with respect to input applied and output generated. Benefit cost ratio is an important aspect in terms of cultivation of any crop. During the present experiment, the total fixed cost was Rs $11500 /-$ and total variable cost was Rs.12763.43/- (Table 1-3).

Table.1 Details of the fixed cost parameters under study

\begin{tabular}{|c|c|c|c|c|c|}
\hline Sr. No. & $\begin{array}{c}\text { Treatment } \\
\text { code }\end{array}$ & $\begin{array}{c}\text { Cost of land } \\
\text { (Rs.) }\end{array}$ & $\begin{array}{c}\text { Management } \\
\text { cost } \mathbf{( 5 \% )}\end{array}$ & $\begin{array}{c}\text { Risk Margin } \\
(\mathbf{1 0 \%})\end{array}$ & $\begin{array}{c}\text { Total } \\
(\text { Rs. })\end{array}$ \\
\hline $\mathbf{1 .}$ & $\mathrm{T}_{1}$ & 1000 & 50 & 100 & 1150 \\
\hline $\mathbf{2 .}$ & $\mathrm{T}_{2}$ & 1000 & 50 & 100 & 1150 \\
\hline $\mathbf{3 .}$ & $\mathrm{T}_{3}$ & 1000 & 50 & 100 & 1150 \\
\hline $\mathbf{4 .}$ & $\mathrm{T}_{4}$ & 1000 & 50 & 100 & 1150 \\
\hline $\mathbf{5 .}$ & $\mathrm{T}_{5}$ & 1000 & 50 & 100 & 1150 \\
\hline $\mathbf{6 .}$ & $\mathrm{T}_{6}$ & 1000 & 50 & 100 & 1150 \\
\hline $\mathbf{7 .}$ & $\mathrm{T}_{7}$ & 1000 & 50 & 100 & 1150 \\
\hline $\mathbf{8 .}$ & $\mathrm{T}_{8}$ & 1000 & 50 & 100 & 1150 \\
\hline $\mathbf{9 .}$ & $\mathrm{T}_{9}$ & 1000 & 50 & 100 & 1150 \\
\hline $\mathbf{1 0 .}$ & $\mathrm{T}_{10}$ & 1000 & 50 & 100 & 1150 \\
\hline & Total & 10000 & 500 & 1000 & 11500 \\
\hline
\end{tabular}

Table.2 Details of the variable cost parameters under study

\begin{tabular}{|c|c|c|c|c|c|c|c|c|}
\hline $\begin{array}{l}\dot{z} \\
\dot{\bar{n}}\end{array}$ & 胥 & 㤩 & 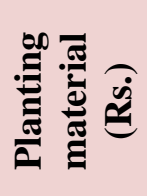 & : & 㫄 & 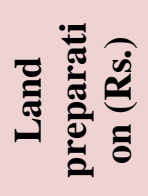 & 氮 & $\stackrel{\tilde{\sigma}}{\stackrel{\tilde{\theta}}{\theta}}$ \\
\hline 1. & $\mathrm{~T}_{1}$ & 1000 & 100 & 2.34 & 0.0028 & 45 & 75 & 1222.34 \\
\hline 2. & $\mathrm{~T}_{2}$ & 1000 & 100 & 2.34 & 0.0084 & 45 & 75 & 1222.35 \\
\hline 3. & $\mathrm{~T}_{3}$ & 1000 & 100 & 2.34 & 0.014 & 45 & 75 & 1222.35 \\
\hline 4. & $\mathrm{~T}_{4}$ & 1000 & 100 & 2.34 & 90 & 45 & 75 & 1312.34 \\
\hline 5. & $\mathrm{~T}_{5}$ & 1000 & 100 & 2.34 & 90 & 45 & 75 & 1312.34 \\
\hline 6. & $\mathrm{~T}_{6}$ & 1000 & 100 & 2.34 & 90 & 45 & 75 & 1312.34 \\
\hline 7. & $\mathrm{~T}_{7}$ & 1000 & 100 & 2.34 & 90.0028 & 45 & 75 & 1312.34 \\
\hline 8. & $\mathrm{~T}_{8}$ & 1000 & 100 & 2.34 & 90.0084 & 45 & 75 & 1312.35 \\
\hline 9. & $\mathrm{~T}_{9}$ & 1000 & 100 & 2.34 & 90.014 & 45 & 75 & 1312.35 \\
\hline \multirow[t]{2}{*}{10.} & $\mathrm{~T}_{10}$ & 1000 & 100 & 2.34 & 0 & 45 & 75 & 1222.34 \\
\hline & Total & 10000 & 1000 & 23.40 & 540.050 & 450 & 750 & 12763.44 \\
\hline
\end{tabular}


Table.3 Treatment wise details of total cost price and selling price

\begin{tabular}{|c|c|c|c|c|c|c|c|}
\hline $\begin{array}{c}\text { Sr. } \\
\text { No. }\end{array}$ & $\begin{array}{c}\text { Treatment } \\
\text { code }\end{array}$ & \multicolumn{3}{|c|}{ Total cost price (Rs.) } & \multicolumn{3}{|c|}{ Total selling price (Rs.) } \\
\cline { 3 - 7 } & & Fixed cost & $\begin{array}{c}\text { Variable } \\
\text { cost }\end{array}$ & Total & $\begin{array}{c}\text { Yield } \\
(\text { Kg) }\end{array}$ & Rate/Kg & Total \\
\hline $\mathbf{1 .}$ & $\mathrm{T}_{1}$ & 1150 & 1222.34 & 2372.34 & 2.83 & 1000 & 2830 \\
\hline $\mathbf{2 .}$ & $\mathrm{T}_{2}$ & 1150 & 1222.35 & 2372.35 & 3.14 & 1000 & 3140 \\
\hline $\mathbf{3 .}$ & $\mathrm{T}_{3}$ & 1150 & 1222.35 & 2372.35 & 3.91 & 1000 & 3910 \\
\hline $\mathbf{4 .}$ & $\mathrm{T}_{4}$ & 1150 & 1312.34 & 2464.34 & 2.62 & 1000 & 2620 \\
\hline $\mathbf{5 .}$ & $\mathrm{T}_{5}$ & 1150 & 1312.34 & 2462.34 & 3.55 & 1000 & 3550 \\
\hline $\mathbf{6 .}$ & $\mathrm{T}_{6}$ & 1150 & 1312.34 & 2462.34 & 3.55 & 1000 & 3550 \\
\hline $\mathbf{7 .}$ & $\mathrm{T}_{7}$ & 1150 & 1312.34 & 2462.34 & 2.89 & 1000 & 2890 \\
\hline $\mathbf{8 .}$ & $\mathrm{T}_{8}$ & 1150 & 1312.35 & 2462.34 & 4.92 & 1000 & 4620 \\
\hline $\mathbf{9 .}$ & $\mathrm{T}_{9}$ & 1150 & 1312.35 & 2462.35 & 4.13 & 1000 & 4130 \\
\hline $\mathbf{1 0 .}$ & $\mathrm{T}_{10}$ & 1150 & 1222.34 & 2372.34 & 2.78 & 1000 & 2780 \\
\hline & Total & 11500 & 12763.44 & 24263.44 & 34.32 & & 34020 \\
\hline
\end{tabular}

Table.4 Treatment wise details showing benefit and Benefit: Cost (B:C ratio)

\begin{tabular}{|c|c|c|c|c|c|}
\hline $\begin{array}{c}\text { Sr. } \\
\text { No. }\end{array}$ & $\begin{array}{c}\text { Treatment } \\
\text { code }\end{array}$ & $\begin{array}{c}\text { Cost price } \\
\text { (Rs.) }\end{array}$ & $\begin{array}{c}\text { Selling price } \\
\text { (Rs.) }\end{array}$ & $\begin{array}{c}\text { Benefit } \\
\text { (Rs.) }\end{array}$ & $\begin{array}{c}\text { B:C } \\
\text { ratio }\end{array}$ \\
\hline $\mathbf{1 .}$ & $\mathrm{T}_{1}$ & 2372.34 & 2830 & 457.66 & 0.19 \\
\hline $\mathbf{2 .}$ & $\mathrm{T}_{2}$ & 2372.35 & 3140 & 767.65 & 0.32 \\
\hline $\mathbf{3 .}$ & $\mathrm{T}_{3}$ & 2372.35 & 3910 & 1537.65 & 0.65 \\
\hline $\mathbf{4 .}$ & $\mathrm{T}_{4}$ & 2464.34 & 2620 & 157.66 & 0.06 \\
\hline $\mathbf{5 .}$ & $\mathrm{T}_{5}$ & 2462.34 & 3550 & 1087.66 & 0.44 \\
\hline $\mathbf{6 .}$ & $\mathrm{T}_{6}$ & 2462.34 & 3550 & 1087.66 & 0.44 \\
\hline $\mathbf{7 .}$ & $\mathrm{T}_{7}$ & 2462.34 & 2890 & 427.66 & 0.17 \\
\hline $\mathbf{8 .}$ & $\mathrm{T}_{8}$ & 2462.34 & 4620 & 2157.65 & 0.87 \\
\hline $\mathbf{9 .}$ & $\mathrm{T}_{9}$ & 2462.35 & 4130 & 1667.65 & 0.67 \\
\hline $\mathbf{1 0 .}$ & $\mathrm{T}_{10}$ & 2372.34 & 2780 & 407.66 & 0.17 \\
\hline & $\mathrm{Total}$ & 24263.44 & 34020 & 9756.56 & \\
\hline
\end{tabular}

Among the different treatment combinations maximum profit was Rs $2157.65 /$ - and benefit cost ratio (0.87:1) was recorded from treatment $\mathrm{T}_{8}$ comprising $\mathrm{ZnSO}_{4} @ 0.1 \%+$ $\mathrm{ZnO}$ nanoparticles@ 150 ppm, whereas the minimum value was observed from treatment $\mathrm{T}_{4}$ ( $\mathrm{ZnO}$ nanoparticles@100 ppm). The benefit cost ratio is worked out under table 4 .

The reason for the maximum cost benefit ratio in treatment combination $\mathrm{T}_{8}$ comprising $\mathrm{ZnSO}_{4} @ 0.3 \%+\mathrm{ZnO}$ NPs@ 150 ppm could be the role of zinc in increasing fruit yield resulting into more returns and ultimately leading to more benefit cost ratio. The results obtained from the present experiment are in accordance with Kumar et al., (2017), Guvvali et al., (2017) and Ekka et al., (2018).

From the study, it may be concluded that the maximum benefit cost ratio (0.87) was observed under treatment combination of $\mathrm{ZnSO}_{4} @ 0.3 \%+\mathrm{ZnO} \mathrm{NPs} @ 150 \mathrm{ppm}\left(\mathrm{T}_{8}\right)$, whereas the least benefit cost ratio $(0.05)$ was observed under treatment $\mathrm{T}_{4}$ ( $\mathrm{ZnO}$ NPs @ $100 \mathrm{ppm})$. Therefore, the treatment 
combination $\mathrm{T}_{8}\left(\mathrm{ZnSO}_{4} @ 0.3 \%+\mathrm{ZnO} \mathrm{NPs}\right.$ @ $150 \mathrm{ppm}$ ) must recommended to farmers of mid hill region of Himachal Pradesh as they can get maximum returns from strawberry cultivation under protected cultivation.

\section{References}

Aslani F, Bugheri S, Julkapli N M, Juraimi A S, Hashemi F S G and Baghdadi A (2014) Effects of engineered nanomaterials on plants growth: an overview. The Scientific World Journal Volume2014 (Article ID 641759):1-28.

Ayub M, Javid U, Muhammad A and Zeb A (2010) Evaluation of strawberry juice preserved with chemical preservatives at refrigeration temperature. International Journal of Nutrition and Metabolism 2(2): 027-032.

Ekka R A, Singh R K, Saravanam S and Kasera S (2018) Foliar application of micronutrients influenced vegetative growth, yield and quality traits of strawberry (Fragaria $\times$ ananassa Duch.) cv. Chandler. Journal of Pharmacognosy and Phytochemistry 7(6): 2030-2032.

Guvvali T, Sampath P M, Shirol A M, Bhaskar R B, Nirmala P and Koulagi S (2017) Influence of micronutrients on growth, yield and economy of sapota cv. Kalipatti under HDP system. International Journal of Agricultural Science and Research 7(31): 401-408.

Kumar J U, Bahadur V, Prasad V M, Mishra S and Shukla P K (2017) Effect of different concentrations of iron oxide and zinc oxide nanoparticles on growth and yield of strawberry (Fragaria $\times$ ananassa Duch.) cv. Chandler. International Journal of Current Microbiology and Applied Sciences 6(8): 2440-2445.

Kumar J U, Bahadur V, Prasad V M, Mishra $S$ and Shukla P K (2017) Effect of different concentrations of iron oxide and zinc oxide nanoparticles on growth and yield of strawberry (Fragaria $\times$ ananassa Duch.) cv. Chandler. International Journal of Current Microbiology and Applied Sciences 6(8): 2440-2445.

Nanderi M R and Abedi A (2012) Application of nanotechnology in agriculture and refinement of environmental pollutants. Journal of Nanotechnology 11(1): 1826.

Pandey N (2010) Role of micronutrients in reproductive physiology of plants. Plant Stress 4(1): 1-13.

Siddiqui M H, Al Whaibi M H, Firoz M and Al Khaishany (2015) Role of nanoparticles in plants. Nanotechnology and Plant Sciences 12: 19-35.

Stiles W C (2004) Micronutrient management in apple orchards. New York Fruit Quarterly 12(1): 28-30.

Yadollahi A, Arzani $\mathrm{K}$ and Khoshghalb $\mathrm{H}$ (2014) The role of nanotechnology in horticultural crop post harvest management. Acta Horticulturae 875: 49-56.

\section{How to cite this article:}

Anjali Thakur, Amit Saurabh and Lakhwinder Kaur. 2021. Effect of Zinc Sulphate and Zinc oxide Nanoparticles on Economic Returns from Strawberry (Fragaria $\times$ ananassa Duch.) cv. Camarosa Cultivation under Protected Conditions of Mid Hills of Himachal Pradesh. Int.J.Curr.Microbiol.App.Sci. 10(02): 1117-1121. doi: https://doi.org/10.20546/ijcmas.2021.1002.131 